\title{
A dinâmica de construção constitucional do Brasil império: entre liberalismo e descentralização
}

\author{
Brazil's constitutional building dynamics between liberalism \\ and decentralization
}

LUCIENE DAL RI

luciene.dalri@univali.br

JAILSON PEREIRA ${ }^{2}$

jailson@jailsonpereira.com.br

GALILEU - REVISTA DE DIREITO E ECONOMIA - e-ISSN 2184-1845

Volume XXI $\cdot 1^{\text {st }}$ January Janeiro $-30^{\text {TH }}$ June Junho $2020 \cdot$ pp. 7-29

DOI: https://doi.org/10.26619/2184-1845.XXI.1.1

Submitted on March $27^{\text {th }}, 2020 \cdot$ Accepted on June $4^{\text {th }}, 2020$

Submetido em 27 de Março, 2020 . Aceite a 4 de junho, 2020

RESUMO O objetivo deste artigo é analisar o movimento constitucionalista brasileiro a partir da sua permeabilidade com o liberalismo e outros movimentos constitucionalistas, principalmente durante a primeira metade do século XIX. Utilizando-se do método de pesquisa indutivo observou-se o reflexo da contraposição de valores e de interesses entre os conservadores e os liberais, na construção constitucional brasileira. A proclamação de independência do Brasil fomenta a contraposição política que vem à contextualizar a resistência à Constituição promulgada em 1824, evidenciando-se assim a busca por um lado para manter o poder tão somente nas mãos do Imperador e por outro para limitar o poder do Estado e promover a descentralização do governo central para as províncias e os municípios.

PALAVRaS CHaVE Liberalismo. Constitucionalismo. Monarquia. Descentralização.

1 Doutora em Direito pela Università degli Studi di Roma - La Sapienza; Mestre em Estudos Medievais pela Pontificia Università Antonianum. Professora no Programa de Mestrado e Doutorado em Ciência Jurídica da Universidade do Vale do Itajaí (UNIVALI) e na graduação em Direito do Centro Universitário Católica de Santa Catarina. O presente artigo se insere nas atividades de pesquisa do Programa de Mestrado e Doutorado em Ciência Jurídica, UNIVALI, em específico na linha de pesquisa em Constitucionalismo e Produção do Direito e no grupo de pesquisa em Estado, Constitucionalismo e Produção de Direito; e nas atividades do grupo de pesquisa Direito na aceleração da dinâmica social e as novas tecnologias, da Escola de Direito da Católica/SC em Joinville.

2 Doutorando do Programa de Pós-Graduação Stricto Sensu em Ciência Jurídica pela UNIVALI (CAPES 6) e pela Delaware Law School (doutorado sanduíche), na linha de pesquisa Constitucionalismo e Produção do Direito. Mestre em Ciência Jurídica pela UNIVALI (CAPES 6), Advogado inscrito na Ordem dos Advogados do Brasil, Seção de Santa Catarina e Seção de São Paulo, Membro do Instituto dos Advogados de Santa Catarina. Professor e Coordenador do Curso de Direito na Faculdade Capivari - FUCAP - Univinte. 


\begin{abstract}
The purpose of this article is to analyze the Brazilian constitutionalist movement from its permeability with liberalism and other constitutionalist movements during the first half of the nineteenth Century. Using the inductive research method, a reflection of the opposition of values and interests between conservatives and liberals was observed in the Brazilian constitutional construction. Brazil's proclamation of independence promotes political opposition that contextualizes the resistance to the Constitution promulgated in 1824, thus evidencing the search on the one hand to maintain power only in the hands of the Emperor and on the other hand, to limit state power and promote decentralization from central government to provinces and municipalities.
\end{abstract}

KEYWORDS Liberalism, Constitucionalism, Monarchy, Decentralization.

\title{
I. Introdução
}

A concepção moderna de constituição é inseparável dos movimentos constitucionalistas e liberais, que visam limitar o poder do Estado e garantir direitos aos indivíduos. Nesse sentido, constata-se que não existe um constitucionalismo, mas diversos movimentos ou doutrinas constitucionalistas que se permeiam. No Brasil, o movimento constitucionalista, na primeira metade do século XIX, denota tanto matizes nacionais quanto a permeabilidade com movimentos constitucionalistas de outros países, antes e depois da proclamação da independência. Os movimentos constitucionalistas e os princípios liberais que o influenciaram eram contrapostos ao absolutismo e à consequente negação ou incerteza de direitos, que não permitia regras claras e segurança nas relações econômicas.

A oposição da monarquia lusitana aos movimentos constitucionalistas atrasou a elaboração de uma constituição e gerou verdadeiras revoluções em Portugal e no Brasil, ocasionando que o primeiro texto sistematizado de natureza constitucional lusófono fosse a "Súplica" à Napoleão $(1808)^{3}$.

3 CANOTILHO, José Joaquim Gomes - Direito constitucional e Teoria da Constituição. 6. ed. Coimbra: Almedina, 1993, p. 149. Na proposta apresentada pelos portugueses a Napoleão não havia a pretensão de convocar uma assembleia constituinte, mas simplesmente o pedido de concessão de uma carta normativa. A "Súplica" era uma proposta que buscava a introdução em Portugal de formas representativas e princípios de igualdade civil e fiscal, liberdades e educação. BONAVIDES, Paulo - Teoria constitucional da democracia participativa. São Paulo: Malheiros, 2001, p. 192. HESPANHA, Manuel - «Sob o signo de Napoleão. A Súplica constitucional de 1808». In: Almanack braziliense. São Paulo. ISSN 1808-8139. V.8, 2008, p. 80-101. 
Por sua vez, o primeiro ato voltado à confecção de uma constituição em terras brasileiras ocorreu por meio da Revolução Pernambucana, movimento de cunho liberal, separatista e republicano que não só estabeleceu o Governo Provisório da República de Pernambuco, como decretou em março de 1817 uma Lei orgânica ${ }^{4}$. A Lei orgânica da República de Pernambuco constava de 28 artigos e pode ser considerada como um ato constituinte provisório, visto que se almejava a elaboração de uma Constituição, por uma Assembleia Constituinte ${ }^{5}$.

$\mathrm{O}$ ato constituinte provisório pernambucano teve a participação de Antônio Carlos Ribeiro de Andrada Machado e Silva ${ }^{6}$, posteriormente deputado na assembleia constituinte brasílica. O texto evidencia concepções de clara inspiração na Revolução Francesa, como a concepção de soberania popular, a liberdade de imprensa e religiosa (mantendo, porém, a religião de Estado), e a referência aos direitos do homem7.

Os ideais de liberdade e a sacralidade da propriedade encontram, porém, sérias dificuldades em lidar com interesses escravocratas e aristocráticos. Os proprietários rurais pernambucanos tinham como principal atividade o cultivo da cana de açúcar, com mão de obra escrava, e viam na possível abolição da escravatura a inviabilidade da plantação canavieira.

O choque de interesses levou os revolucionários republicanos a dialogar com os proprietários rurais, visando acalmá-los diante da proclamação do governo provisório que atestava a igualdade dos homens, independentemente de cor, muito embora aceitasse e "defendesse" a sacralidade e a inviolabilidade da propriedade. Impelida pelos interesses opostos, o governo, então, defendeu um processo de abolição "lento, regular e legal".

O caráter liberal da Revolução Pernambucana, apesar de esbarrar nos interesses das elites dos proprietários agrícolas, ainda refletia a influência francesa e estadunidense e se refletiu em outros movimentos, como a independência do Brasil e a abdicação de Dom Pedro I, em $1931 .^{9}$

4 Dentre os fatores que causaram a revolta pernambucana estão os gastos da Corte no Rio de Janeiro; a rivalidade entre Brasileiros e Portugueses; a influência da Independência dos EUA; a influência da Revolução Francesa e a independência de algumas colônias espanholas. BONAVIDES, Paulo - «As nascentes do constitucionalismo lusobrasileiro, uma análise comparativa». [Consultado em 03 de Novembro de 2019] Disponível em: https://archivos. juridicas.unam.mx/www/bjv/libros/4/1510/9.pdf.

5 BONAVIDES, Paulo - Teoria constitucional da democracia ..., p. 193.

6 Antonio Carlos Ribeiro de Andrada e Silva nasceu em Santos, em 1773, estudou em Coimbra e participou da revolução pernambucana de 1817. Com o insucesso da revolta foi condenado a 4 anos de prisão.

7 BONAVIDES, Paulo - Teoria constitucional da democracia ..., p. 193.

8 Proclamação do Governo Provisório aos patriotas pernambucanos - In BONAVIDES, Paulo; AMARAL, Roberto (orgs.) - Textos Políticos da História do Brasil. Brasília: Senado Federal, Conselho editorial, 2002, p. 481.

9 FAORO, Raymundo - Os Donos do Poder. Formação do patronato político brasileiro. $5{ }^{\text {a }}$ ed. Rio de Janeiro: Editora Globo, 2018, p. 301: "A aliança entre propriedade agrária e liberalismo, visível nos demagogos letrados, entrelaçada pelos padres cultos, pelos leitores dos enciclopedistas e pelos admiradores da emancipação norte-americana, ensaia seus primeiros e vigorosos passos, que darão os elementos de luta nos dias agitados de 1822 e expulsarão 


\section{Da vigência da Constituição de Cádiz à Constituição Vintista}

Antes mesmo da independência do Brasil, D. João VI, em 21 de abril de 1821, por meio de decreto, ordenava a vigência interina da Constituição espanhola de 1812, desde a data do decreto "até a instalação da Constituição em que trabalharão as cortes atuais de Lisboa"10. Muito embora tenha vigorado apenas um dia, o decreto sobre a Constituição de Cádiz evidenciou a influência do constitucionalismo espanhol sobre aquele português e brasileiro, trazendo à público as linhas mestras da elaboração da constituição "vintista" e posteriormente da constituição brasileira de $1824^{11}$.

A primeira Constituição portuguesa foi fruto das Cortes gerais, extraordinárias e constituintes, eleitas pela Nação e compostas por 130 deputados de Portugal e 75 provenientes do Brasil. O trabalho das Cortes Gerais foi sentido no Brasil também pela intrincada participação dos deputados brasileiros que tentaram manter a autonomia nacional e a união constitucional dos dois reinos, mas defrontaram-se com uma política de governo portuguesa centralizadora e que buscava reduzir o status politico do Brasil.

Se no jogo de forças políticas os liberais estavam comprometidos com a soberania popular, os conservadores por sua vez fixavam suas forças na mantença das tradições da monarquia e, nesse cenário discutia-se também fortemente a organização do poder do Estado e a centralização ou descentralização político administrativa do império português e posteriormente do Brasil.

Tal fato fomenta ainda mais a luta pela autonomia política brasileira em relação à Portugal, ao ponto de antes mesmo da independência ter-se a convocação da "Assembleia Geral Brasílica e Constituinte e Legislativa", por meio do decreto de 03 de junho de 1822. Evidencia-se ainda que apenas três meses após a convocação da assembleia constituinte e sem

o imperador em 1831". Alerta Faoro, porém, que a aliança não teve a capacidade de promover a organização do estado na forma como pretendia, mas que o movimento é uma “...amostra de uma tendência possível, como possível foi o processo de independência e de fragmentação do mundo americano espanhol. ” E continua: "A Revolução de 1817 deixou no solo germes de revivescimento, que se prolongarão em 1824, na Confederação do Equador. Definiu num ideário, que se prolonga no curso de todo o Império, com o liberalismo forrado de energia republicana". FAORO, Raymundo - Os Donos do Poder.... 5. ${ }^{\text {a }}$ ed., p. 303.

10 BRASIL. Decreto de Dom João VI, de 21 de abril de 1821. In BONAVIDES, Paulo; AMARAL, Roberto (orgs.) - Textos Políticos da História ..., p. 493. Sobre a Constituição de Cádiz e seu influxo na América Latina, ver: RESTREPO, Ricardo Sanín «A Constituição de Cadiz ou a antimatéria da Democracia Latino-Americana». In: Revista NEJ Eletrônica. ISSN Eletrônico 2175-0491, Vol. 16 - n. 3 - p. 305-315 / set-dez 2011.

11 A constituição espanhola previa em seu artigo 4. "A nação está obrigada a conservar e proteger, por leis sábias e justas a liberdade civil, a propriedade e mais direitos legítimos de todos os indivíduos que a compõem". Constituição de Cádiz, Constituição Política da Nação Espanhola (19 de março de 1812). "A Constituição de Cádiz fora deveras relevante em determinar as bases liberais da primeira Carta Magna de Portugal: a chamada 'Constituição vintista' de 23 de setembro de 1822”. A constituição portuguesa de 23 de setembro de 1822 foi vigente durante dois curtos períodos, entre 1822 e 1823, e de 1836 a 1838. BONAVIDES, Paulo - «A evolução constitucional do Brasil». In: Estudos Avançados. São Paulo. ISSN 0103-4014. Vol. 14, N. . 40, 2000, p. 156. BONAVIDES, Paulo Teoria constitucional da ..., p. 194. 
luta armada, houve a proclamação da independência do Brasil, em 7 de setembro de 1822, afastando o Brasil da promulgação da Constituição portuguesa, que ocorreu em outubro de 1822 .

O texto constitucional "vintista", desde o preâmbulo, denota a influência do movimento liberal, presente na conspiração de Gomes Freire, em 1817, e na Revolução do Porto, de 1820, assegurando 'direitos do cidadão' e 'leis fundamentais da monarquia', e na Constituição de Cádiz, de 1812 que propunha conservar e proteger a liberdade civil, a propriedade e os demais direitos legítimos dos cidadãos espanhóis ${ }^{12}$.

O movimento liberal português para a afirmação de uma constituição e de direitos individuais não se reflete, portanto, numa política de descentralização de governo e devido a tal fato afasta-se daquele brasileiro, que teve forte influência no âmbito jurídico e político da independência ${ }^{13}$.

\section{A Independência e o Movimento Constitucionalista}

Se como evidencia Vieira ${ }^{14}$, a orientação dada às constituições brasileiras tem sido, em linhas gerais, orientada por princípios liberais como a separação de poderes, os direitos individuais e a representação política, mas também seguiu a linha traçada pelos demais países latino-americanos, durante a sua formação, onde a ordem liberal possibilitou a sua integração em nível internacional; para Bonavides ${ }^{15}$, as formas como o Brasil e os demais países latino-americanos adequaram-se ao constitucionalismo são sensivelmente diferentes. O Brasil não rompeu com o passado europeu, com o antigo regime, mas o transformou dentro do que era necessário para a sua sobrevivência.

Nesse contexto, denota-se que o processo de independência e de constitucionalização brasileiro é autônomo e original, se comparado aos países hispano-americanos que "foram teatro de um confronto armado com a metrópole colonial, verdadeira revolução da inde-

12 A declaração de "direitos e deveres individuais", da Constituição, assegura nos seus artigos $1 .^{\circ}$ ao $19 .^{\circ}$ a liberdade, igualdade, segurança e propriedade de todos os cidadãos. Nesta, extinguia-se a tortura, previa-se o direito de petição e a inviolabilidade de domicílio e de correspondência, bem como se quebrava a concepção de cargo ou função pública como patrimônio pessoal de seu ocupante.

13 LOPES, José Reinaldo de Lima - O Direito na História: lições introdutórias. 3. ed. São Paulo: Atlas, 2008, p. 255.

14 Vieira evidencia o debate sobre a articulação do modelo liberal nas constituições brasileiras. Segundo o autor podemos reduzir o debate a três linhas teóricas: 1 - afirma que os princípios liberais tornaram-se algo abstrato e formal nas constituições brasileiras devido à incapacidade das elites e a inexistência de uma ordem burguesa; 2 - afirma que a ordem liberal foi "importada", sendo "ideias fora do lugar"; 3 - afirma que a ordem liberal surge na sociedade brasileira como fruto das articulações sociais das relações de produção. VIEIRA, José Ribas - O autoritarismo e a ordem constitucional no Brasil. São Paulo: Renovar, 1988, p. 47 e 53.

15 "O influxo europeu, inglês e continental sobre o constitucionalismo brasileiro é traço marcante dos primeiros momentos de definição do nosso estatuto institucional". Cf. BONAVIDES, Paulo - «A evolução constitucional do Brasil». In: Estudos Avançados. São Paulo. ISSN 0103-4014. Vol. 14, N. . ${ }^{40}$, 2000, p. 156. 
pendência" e que implicou desde o princípio em uma ruptura sem alternativa, com o reino de Espanha ${ }^{16}$.

No mesmo sentido, para Faoro, "O regime colonial não se extingue, moderniza-se; os remanescentes bragantinos se atualizam, com a permanência do divórcio entre o Estado, monumental, aparatoso, pesado e a nação, informe, indefinida, inquieta” ${ }^{17}$.

Mesmo com essas possíveis vertentes quanto ao constitucionalismo brasileiro, o liberalismo revela-se nesse primeiro momento amplamente vinculado à temas da autonomia nacional, de patriotismo e de ruptura do domínio português, sendo contrário ao sistema colonial mais do que à monarquia. Buscava-se maior autonomia para o comércio, a justiça, e a administração pública ${ }^{18}$. O ideal republicano, que insurgia nas revoluções, não era compartilhado por todos os opositores da política e da administração reacionária portuguesa ${ }^{19}$.

O controle e a limitação do poder são elementos mais importantes para o liberalismo do que a definição de quem detém o poder ${ }^{20}$. Nesse sentido, o constitucionalismo tornou-se o instrumento de consubstanciação do liberalismo, defendia a descentralização do Estado, o sistema bicameral (enfraquecendo o legislativo), o sufrágio eleitoral com um baixo censo, a independência judicial e o sistema de júri, e a proteção de opinião pública, por meio de leis de imprensa ${ }^{21}$. A limitação do poder e a luta pela autonomia nacional são elementos comungados por todos os liberais naquele momento histórico.

A Assembleia instaurada apenas em 1823 deveria ter sido composta por 100 membros eleitos indiretamente, mas acabou sendo composta apenas por 89 representantes das províncias. O primeiro projeto de constituição brasileira teve forte influência do constitucionalismo europeu, tanto continental quanto inglês e foi muito marcada pela convicção liberal dos Andradas ${ }^{22}$.

16 FRANCO, Afonso Arinos de Melo - Introdução. In O Constitucionalismo de D. Pedro I no Brasil e em Portugal. Brasília: Ministério da Justiça, 1994, p. 22. BONAVIDES, Paulo - «As nascentes do constitucionalismo lusobrasileiro...», p. 200. [Consultado em 03 de Outubro de 2019] Disponível em: https://archivos.juridicas.unam.mx/ www/bju/libros/4/1510/9.pdf.

17 FAORO, Raymundo - Os Donos do Poder. Formação do patronato político brasileiro. 5. ${ }^{a}$ ed. Rio de Janeiro: Editora Globo, 2018, p. 331.

18 BONAVIDES, Paulo - História constitucional do Brasil. Rio de Janeiro: Paz e Terra, 1991, p. 6.

19 Sobre liberalismo e democracia no século XIX, ver BOBBIO, Norberto - Liberalismo e Democracia. São Paulo: Brasiliense, 2000, p. 53.

20 BOBBIO, Norberto - Liberalismo e Democracia, p. 55; CANOTILHO, José Joaquim Gomes - Direito constitucional.... 6. ed., p. 54 .

21 HESPANHA, António Manuel - «Pequenas repúblicas, grandes Estados. Problemas de organização política entre antigo regime e liberalismo». In: Brasil. Formação do Estado e da Nação. São Paulo-Ijuí: Ed. Unijuí, 2003, p. 103

22 PIRES, Alex Sander Xavier; TRINDADE, Carla Dolezel; AZNAR Filho, Simão - Constitucionalismo Luso-Brasileiro - leitura normativa no âmbito do domínio da lei e da humanização das relações. Rio de Janeiro, 2017, p. 17: "Se a Constituição Portuguesa de 1822 não produziu seus regulares efeitos no Brasil, ao menos serviu de inspiração para a Assembleia Constituinte Brasileira reunida para elaborar um texto constitucional específico para o novo Estado independente". 
Em sua atuação, optando por uma tendência liberal e democratizante, a assembleia privou o monarca da faculdade de vetar os decretos da casa, afirmando a soberania do colégio em detrimento das competências imperiais ${ }^{23}$. A pluralidade de funções fez com que a Assembleia Geral, em sua primeira sessão ordinária cria-se a Comissão de Constituição, para a confecção do projeto constitucional, sendo composta por Antônio Carlos Ribeiro de Andrada, Antônio Luís Pereira da Cunha, Pedro de Araujo Lima, José Ricardo da Costa Aguiar, Manoel Ferreira da Câmara Bithencourt e Sá, Francisco Muniz Tavares e José Bonifácio de Andrada e Silva ${ }^{24}$.

No projeto apresentado pela Assembleia, o imperador seria uma autoridade sagrada e inviolável, que não poderia ser responsabilizada por seus atos. O imperador então exerceria o poder executivo, mas seus atos seriam obrigatórios apenas com o referendo dos ministros de governo, que lhe assumiriam a responsabilidade ${ }^{25}$. A autoridade inviolável e não responsável do imperador era então distinta da autoridade dos ministros de governo, afastando-o do exercício direto da atividade governamental. Diminuiu-se consideravelmente também seu poder em relação à atividade parlamentar e aos parlamentares, como bem se observa com a dispensa da ratificação imperial para a validade de normas jurídicas provenientes da Assembleia Geral e a impossibilidade de dissolver a Câmara dos Deputados ${ }^{26}$.

Diante do esboço apresentado e devido a sua limitação de poderes, o imperador dissolveu a Assembleia Geral e criou o Conselho que passou a desenvolver o texto da Constituição

23 A Assembleia promulgou seis leis, sem a sanção do imperador, ampliando a divergência entre a Coroa e a Assembleia, que resultou na sua dissolução. "Juridicamente a razão estava com a Coroa. A Constituinte não era depositária única da soberania, visto que sua existência dependera da convocação da Coroa preexistente, que ela reconhecera pelo simples fato de haver atendido à convocação. Sobretudo, depois de ocorrida a independência e aclamado o Imperador, a Coroa, não como pessoa, mas como órgão, era parte da soberania do Estado". FRANCO, Afonso Arinos de Melo - «Introdução». In: O constitucionalismo de D. Pedro I no Brasil e em Portugal. Brasília: Ministério da Justiça, 1994, p. 24.

24 BRASIL. Congresso Nacional. Câmara dos Deputados. Coordenação de Arquivo. Inventário analítico do arquivo da Assembleia Geral Constituinte e Legislativa do Império do Brasil, 1823 [recurso eletrônico] / Câmara dos Deputados. - 2. ed., rev. e reform. - Brasília: Câmara dos Deputados, Edições Câmara, 2015. - (Série coleções especiais. Acervo arquivístico; n. 2), p. 39, 49 s., p. 67. Disponível em https://arquivohistorico.camara.leg.br/atom/ AC1823/sobre/Inventario_AnaliticoAcervoConstituinte1823.pdf.Acesso em 14/01/2019.

25 Ver Versão do Projeto de Constituição para o Império do Brazil, publicado em BRASIL. Congresso Nacional. Câmara dos Deputados. Coordenação de Arquivo. Inventário analítico do arquivo da Assembleia Geral Constituinte e Legislativa do Império do Brasil, 1823 [recurso eletrônico] / Câmara dos Deputados. - 2. ed., rev. e reform. - Brasília: Câmara dos Deputados, Edições Câmara, 2015. - (Série coleções especiais. Acervo arquivístico; n. 2), artigos 138, 139, 174 e 175 [Consultado em: 14 de Outubro de 2019] Disponível em https://arquivohistorico. camara.leg.br/atom/AC1823/sobre/Inventario_AnaliticoAcervoConstituinte1823.pdf.

26 Ver Versão do Projecto de Constituição para o Império do Brazil, publicado em BRASIL. Congresso Nacional. Câmara dos Deputados. Coordenação de Arquivo. Inventário analítico do arquivo da Assembleia Geral Constituinte e Legislativa do Império do Brasil, 1823 [recurso eletrônico] / Câmara dos Deputados. - 2. ${ }^{a}$ ed., rev. e reform. - Brasília: Câmara dos Deputados, Edições Câmara, 2015. - (Série coleções especiais. Acervo arquivístico; n. 2), artigos 110-121. [Consultado em 14 de Outubro de 2019] Disponível em https://arquivohistorico.camara.leg.br/ atom/AC1823/sobre/Inventario_AnaliticoAcervoConstituinte1823.pdf. 
outorgada ${ }^{27}$. O esboço de 1823 foi, porém, amplamente considerado pelo Conselho de Estado que lhe fez aperfeiçoamentos técnicos de sistematização e linguagem, ampliou a atribuição de poderes e manteve a irresponsabilidade dos atos do imperador, por meio da introdução do Poder Moderador ${ }^{28}$

O Poder Moderador não fazia parte do constitucionalismo português e a sua presença na Constituição brasileira de 1824 ocorreu por meio dos trabalhos de revisão do projeto constitucional pelo Conselho de Estado, remontando à teoria do poder neutro, de Benjamin Constant e com claro apelo ao constitucionalismo inglês ${ }^{29}$. Na teoria de Constant, o poder neutro também seria um dos mecanismos para evitar o despotismo do povo, garantindo junto com os direitos civis, a limitação da soberania popular.

O Poder Moderador é apresentado no texto constitucional como "chave de toda a organização Política", tendo competências que permitiram sob Dom Pedro I e a primeira parte do reinado de Dom Pedro II a ingerência imperial sobre os poderes legislativo, executivo e judiciário ${ }^{30}$. A vantagem do poder neutro estava exatamente na sobreposição do monarca e

27 - Sobre a instalação e dissolução da Assembleia Constituinte de 1823, bem como a outorga da Constituição de 1824, ver: Silva (1998, p. 76), CERQUEIRA, Marcello - Cartas Constitucionais: Império, República e Autoritarismo. Rio de Janeiro: Renovar, 1997, p. 33 e Lopes (2008, p. 258).

28 A redação final da Constituição de 1824 teria sido atribuída à Maciel da Costa e Carneiro de Campos. Sobre a formação do Conselho de Estado, ver TORRES, João Camilo de Oliveira - A democracia coroada [recurso eletrônico]: teoria política do Império do Brasil. Brasília: Câmara dos Deputados, Edições Câmara, 2017, p. 526 ss. Sobre proximidades e diferenças entre o Projeto apresentado por Antonio Carlos e a Constituição de 1824, ver MELLO, F.I. Marcondes Homem de - Escriptos históricos e literários. 2. ${ }^{\text {a }}$ ed. Rio de Janeiro, 1866, p. 57 ss. BONAVIDES, Paulo - «As nascentes do constitucionalismo luso-brasileiro, uma análise comparativa», p. 227. [Consultado em: 30 de Agosto de 2019] Disponível em https://archivos.juridicas.unam.mx/www/bjv/libros/4/1510/9.pdf: "O novo projeto foi enviado para às câmaras municipais para aprovação".

29 Considerando que a influência não implica necessariamente em fidelidade à teoria de Constant, observa-se dissonância na doutrina sobre o tema, por um lado alegando que a teoria foi desfigurada devido à pretensão absolutista ou por outro afirmando que houve apenas as necessárias adaptações ao contexto brasileiro, mantendo uma monarquia limitada. O primeiro posicionamento é defendido por: CARNEIRO DA CUNHA, Pedro Octavio- «A Fundação de um Império Liberal». In: S. B. de Holanda (org.). História Geral da Civilização Brasileira. 6. a ed. São Paulo: Difel, Tomo II, vol. 1, 1985, p. 256); BONAVIDES, Paulo - «O poder moderador na Constituição do Império». In: Revista de informação legislativa. Janeiro à março de 1974, p. 28. FAUSTO, Bóris História do Brasil. 7. ed. São Paulo, Editora da USP, 1999, p. 152. FAORO, Raymundo - Os Donos do Poder.... 5. ${ }^{\mathrm{a}}$ ed., p. 333. Nas palavras de Bonavides, porém, o poder moderador possuía "primazia sobre os demais poderes, o que sem dúvida se arredava da teorização de Benjamin Constant, contrariando-a desde as bases". O segundo posicionamento é defendido por: PIMENTA BUENO, José Antônio - Marquês de São Vicente. São Paulo: Editora 34, 2002, p. 96. LYNCH, Christian Edward Cyril - «O Discurso Político Monarquiano e a Recepção do Conceito de Poder Moderador no Brasil (1822-1824)». In: DADOS - Revista de Ciências Sociais. Rio de Janeiro, Vol. 48, n o 3 , 2005 , p. 642.

30 Os dispositivos de divisão de poderes acabam encontrando eficácia apenas a partir de 1826, quando é instalado o Parlamento e dois anos mais tarde quando se cria o Supremo Tribunal de Justiça, no Brasil. NOGUEIRA, Octaviano - 1824. 3. a ed. Brasília: Senado Federal, Coordenação de Edições Técnicas, 2018, p. 18. BRASIL. Constituição Política do Império do Brazil, 1824, ver artigos 98 e 101: "nomear os Senadores; convocar a Assembléa Geral extraordinariamente nos intervalos das Sessões; sancionar os Decretos e Resoluções da Assembléa Geral, para que tenham força de Lei; aprovar, e suspender as Resoluções dos Conselhos Provinciais; prorrogar, ou adiar a Assembléa Geral, e dissolver a Camara dos Deputados, nos casos, em que o exigir a salvação 
se perderia se houvesse o rebaixamento do poder real ao nível do poder executivo, pois duas questões indissolúveis surgiriam: a destituição do poder executivo e a responsabilidade do monarca ${ }^{31}$.

A oposição ao texto constitucional e ao Poder Moderador são evidenciadas nos debates políticos de época. A defesa do Poder Moderador e da separação em quatro poderes, por meio da forte referência ao modelo inglês, era presente entre os conservadores ${ }^{32}$. As atribuições do Poder Moderador seriam então necessárias, pois não poderiam ser exercidas pela nação em massa, cabendo a sua delegação apenas ao imperador ${ }^{33}$. Nesse sentido, a inviolabilidade do imperador não é derivada da responsabilidade dos ministros pelos atos de governo, mas é consequência do princípio da representação nacional, assim como da perpetuidade do chefe de Estado nas monarquias ${ }^{34}$.

Paulino José Soares de Sousa, Visconde do Uruguai, com frequência comparava o sistema brasileiro àquele inglês, francês e americano, com clara preferência ao modelo britânico. Nesse contexto e tendo a referência à Constant, o Visconde defendia o Poder Moderador como instrumento mediador dos conflitos políticos e independente do referendo dos ministros do Poder Executivo ${ }^{35}$.

Por sua vez, na pauta comum aos liberais, encontra-se a defesa da limitação dos poderes imperiais, por meio da afirmação "o rei reina e não governa", difundindo-se a crítica de atribuição do poder executivo ao imperador, mesmo que condicionado à atuação dos ministros de Estado.

Indo além do Poder Moderador, observa-se que a Constituição Política do Império do Brazil, de 1824, correspondia às expectativas da época, apresentando além da soberania nacional e da irresponsabilidade imperial, a separação de poderes, o bicameralismo legislativo, as eleições para ambas as casas, com censo baixo, bem como um considerável capítulo sobre direitos civis, reconhecendo direitos políticos também aos analfabetos. O texto reflete também a inspiração nos princípios do constitucionalismo inglês ao afirmar que é consti-

do Estado e convocar outra, que a substitua; nomear, e demitir livremente os Ministros de Estado; suspender os Magistrados quando houver queixas contra eles; perdoar, e moderar as penas impostas; conceder Amnistia em caso urgente, e que assim aconselhem a humanidade, e bem do Estado".

31 CONSTANT, Benjamin - Principes de politique applicables a tous les gouvernemens représentatifs et particulièrment a la constitution actuelle de la France. Paris: Ches Alexis Eymery, De l'imprimerie de Hocquet, 1815, p. 40: "Le roi, dans un pays libre, est un être à part, supérieur aux diversitès des opinions, n'ayant d'autre intérêt que le maintien de l'ordre, et le maintien de la liberté, ne pouvant jamais rentrer dans la condition commune, inaccessible em conséquence à toutes les passions que cette condition naître, et à toutes celles que la perspective de s'y retrouver nourrit nécessairement dans le coeur des agens investis d'une puissance momentanée".

32 PIMENTA BUENO, José Antônio - Marquês de São ..., p. 107.

33 PIMENTA BUENO, José Antônio - Marquês de São ..., p. 284.

34 BRAZ, Florentino Henrique de Souza - Do poder moderador. Recife: Typographia Universal, 1864, p. 66 e 70 s.

35 URUGUAI, Visconde do - Visconde do Uruguai. Org. e introd. de José Murilo de Carvalho. São Paulo: Editora 34, 2002, p. 323, 339357 ss. e 401 ss. 
tucional apenas o que concerne aos poderes do Estado e aos direitos e garantias individuais, contribuindo para a longevidade do texto constitucional brasileiro ${ }^{36}$.

A gradual inserção de direitos nos constitucionalismos francês, estadunidense, espanhol e português fundamenta histórica e juridicamente a presença de direitos e garantias na Constituição brasileira ${ }^{37}$. A influência liberal por meio da declaração de direitos civis, muito embora seja reverenciada, está presente apenas no último artigo do texto constitucional, contrastando com a constituição portuguesa "vintista" (1822) que a prevê desde seu primeiro artigo da Constituição. Mesmo a participação da população na "comunhão política", por meio do voto censitário e indireto, é descrita apenas a partir do artigo 91.

Não ocorre, porém, na Constituição de 1824, menção alguma à liberdade dos negros, pois os artigos do projeto de 1823 que tratavam sobre a sua emancipação foram retirados do texto constitucional outorgado. As linhas gerais dos direitos presentes na Constituição imperial eram voltadas a afirmar um forte individualismo econômico, bem observado por meio da legitimação do "cidadão-proprietário" e a exclusão dos direitos políticos da maioria da população do país, porquanto seriam reconhecidos apenas aos cidadãos que, por atingirem certa renda, seriam 'independentes' 38 .

O texto constitucional segue, então, uma filosofia política de aguçamento da concepção de liberdade civil com base econômica, presente nas obras de James Harrington, de Immanuel Kant e de Benjamin Constant que justificam a condição censitária dos direitos políticos com a necessidade de confiar o direito de voto somente aos cidadãos que usufruam de certa "independência civil", porque titulares de bens que substancialmente os tornem senhores de si mesmos ${ }^{39}$.

36 NOGUEIRA, Octaviano - 1824. 3. ${ }^{\mathrm{a}}$ ed., p. 10.

37 Os direitos civis dos cidadãos brasileiros têm por base a liberdade, a segurança individual, e a propriedade. Direitos típicos do liberalismo e das Declarações de direitos do século XVIII. Ver: BRAZIL, Constituição Política do Império do Brasil, 1824, "Art. 179. A inviolabilidade dos Direitos Civis, e Políticos dos Cidadãos Brasileiros, que tem por base a liberdade, a segurança individual, e a propriedade, é garantida pela Constituição do Império, pela maneira seguinte". The Virginia declaration of rights (1776) e a Declaration des Droits de l'homme et du Citoyen (1789).

38 WOLKMER, Antonio Carlos - História do Direito no Brasil. 5. ed. Rio de Janeiro: ed. Forense, 2009, p. 108. Sobre a construção da cidadania e de direitos no Brasil, ver DAL RI, Luciene - «A construção da cidadania no Brasil: entre Império e Primeira República». In: Espaço Jurídico Journal of Law [EJJL]. Joaçaba. E- ISSN 2179-7943, vol. 11(1), p. 7-36, 2011.

39 A ideia concernente à importância de uma mínima condição econômica dos cidadãos é presente na obra de Aristóteles (Politica. 4. ed. Roma-Bari: Laterza, 1997, p. 135). Para o filósofo grego a melhor forma de chegar à constituição ideal, harmônica e, portanto, estável, ocorre através da construção de uma ampla classe de cidadãos com uma situação econômica mediana, que lhe permita uma vida independente, formando um forte elemento de moderação do conflito social. O aguçamento da concepção de liberdade civil com base econômica é bem presente nas obras de James Harrington (The Commonwealth of Oceana, disponivel em: http://www.constitution. org/jh/oceana.htm), Immanuel Kant (Über den Gemeinspruch 'Das mag in der Theorie richtig sein, taugt aber nicht fûr die Praxis'. Frankfurt-am-Main: Klostermann, 1992, p. 62) e Benjamin Constant (Escritos de política. São Paulo: 
A distinção entre a cidadania passiva, que abarca a todos os nacionais da nação, e a cidadania ativa (política), privilégio de alguns, fundamenta o enfoque "juridicista" em que a cidadania reduz-se ao vínculo jurídico com o Estado-nação, em cuja "comunhão política" não todos necessariamente participam ${ }^{40}$.

Nesse sentido, a cidadania passiva constitui o laço jurídico por meio do qual todos os cidadãos recebem as garantias jurídicas do Estado e tem como direito mais fortemente presente a liberdade ${ }^{41}$.

O Brasil muito embora tenha incorporado elementos das revoluções liberais por meio da presença de direitos em sua primeira constituição, manteve aspectos da monarquia portuguesa, como a clara tendência ao absolutismo monárquico ${ }^{42}$. Muito embora, o fracionamento da América espanhola e as 'juntas provisórias de governo independente', decretadas por D. João VI, em 1821, tivessem dado força para o fracionamento político e administrativo do território brasileiro, essa aspiração foi embargada pela reação conservadora, que manteve a centralização do poder e a forma unitária do Estado.

Martins Fontes, 2005, p. 282), que apresentam a condição censitária dos direitos políticos como a necessidade de confiar o direito de voto somente aos cidadãos que usufruam de certa independência civil, porque titulares de certa propriedade, que substancialmente os torne senhores de si mesmos. Com mais detalhes sobre o tema: FERREIRA, Manuel Rodrigues - A evolução do Sistema Eleitoral Brasileiro. Brasília: Senado Federal, 2001, p. 130; FIORAVANTI, Maurizio - Costituzione. Bologna: Il Mulino, 1999, p. 20, p. 89; DAL RI Jr., Arno - «Evolução histórica e fundamentos políticos-jurídicos da cidadania». In: DAL RI JR., Arno; OLIVEIRA, Maria Odete de (org.) - Cidadania e Nacionalidade: efeitos e perspectivas: nacionais - regionais - globais. Ijuí: Unijuí, 2002, p. 66; HESPANHA, António Manuel - «Pequenas repúblicas, grandes Estados. Problemas de organização política entre antigo regime e liberalismo». In: Brasil. Formação do Estado e da Nação. São Paulo-Ijuí:Ed. Unijuí, 2003, p. 104.

40 CORRÊA, Darcísio - A construção da cidadania. Reflexões histórico-políticas. Ijuí: Unijuí, 2006, p. 218. A distinção entre cidadania ativa e passiva foi apresentada por Sieyes em (1789, p. 36): “Tous les habitants d' un pays doivent y jouir des droits de citoyen passif: tous ont droit à la protection de leur personne, de leur propriété, de leur liberté, etc; mais tous n'ont pas droit à prendre une part active dans la formation des pouvoirs publics: tous ne son pas citoyens actifs. Les femmes, du moins dans l'état actuel, les enfants, les étrangers, ceux encore qui ne contribueroient en rien à soutenir l'établissement public, ne doivent point influer activement sur la chose publique. Tous peuvent jouir des avantages de la société; mais ceux-là seuls qui contribuent à l'établissement public, sont comme les vrais actionnaires de la grande entreprise sociale. Eux seuls sont les véritables citoyens actifs, les véritables membres de l'association".

41 Sobre direito políticos no Brasil imperial, ver DAL RI, Luciene - «Os direitos políticos no Brasil Imperial: entre constitucionalismo e liberalismo». In: Direitos Fundamentais \& Justiça. Porto Alegre. ISSN 0100-9079, vol. 18, 2012, p. 129-148,

42 "Foi uma constituição liberal, no reconhecimento de direitos, não obstante autoritária, se examinarmos a soma de poderes que se concentram nas mãos do Imperador. É verdade que instituiu a supremacia do homemproprietário. Só este era full-member (isto é membro completo) do corpo social. Mas nisto fez coro a Locke e à ideologia liberal. Esta marcou sua profunda influência no processo da independência e formação política do Brasil, como bem sustentou Vicente Barreto". "As instituições brasileiras dariam continuidade ao direito português" também no Direito público (HERKENHOFF, João Baptista - Como funciona a cidadania. 2 ed. Manaus: Editora Valer, 2001, p. 67). Ver sobre o tema: CERQUEIRA, Marcello - Cartas Constitucionais: Império, República e Autoritarismo. Rio de Janeiro: Renovar, 1997, p. 33; HORTA, José Luiz Borges - Direito Constitucional da Educação. Belo Horizonte: Editora Decálogo, 2007, p. 39; NOGUEIRA, Octaciano - «Voluntarismo jurídico e o desafio institucional». In: Revista do Tribunal Regional Federal da 1. ${ }^{a}$ Região. Brasília, Vol. 9, n. 3, 1997, p. 26. 
A manutenção da monarquia com a Independência e após ela, objetivava maior estabilidade em relação à república, visto as experiências da França revolucionária e dos demais países latino-americanos. A pretensão de estabilidade não é, porém, concretizada a fundo por conta das revoluções e crises institucionais que surgem durante todo o primeiro período imperial.

\section{Da Resistência à Constituição e ao Poder Moderador}

Durante o primeiro reinado, o liberalismo era quase uma ideia subversiva no primeiro reinado, por buscar uma ulterior ruptura com Portugal e fomentar várias manifestações que visavam um novo embasamento para a organização social e política do Brasil. A descentralização era uma das pautas mais frequentes, com fortes críticas ao Poder Moderador, ao Senado vitalício e ao Conselho de Estado ${ }^{43}$. De fato, a abdicação de Dom Pedro I é ocasionada em grande parte por revoltas, pela crise econômica e pela pressão dos proprietários agrários para liberalizar a política.

A centralização política do texto constitucional e a manutenção do poder nas mãos no monarca fez eclodir, em 1824, o movimento da Confederação do Equador, uma revolta armada, liderada entre outros por Frei Caneca, onde foi firmada forte oposição liberal à constituição e ao Imperador. ${ }^{44}$ Denotando liberalismo radical, Frei Caneca evidenciava as distorções brasileiras diante da teoria de Benjamin Constant. A contrariedade à centralização política imposta pelo Imperador D. Pedro I, assim como a contínua influência de Portugal na vida política brasileira, mesmo já independente, insuflaram a revolta ${ }^{45}$.

43 Dentre os liberais, evidencia-se: Antônio Carlos Ribeiro de Andrada Machado e Silva, Manuel Alves Branco, Holanda Cavalcanti, Teófilo Ottoni, Zacarias de Góis e Vasconcelos, Nabuco de Araújo. Martinho Campos, Visconde de Sinimbu, José Antonio Saraiva, Souza Franco, Silveira Martins e Rui Barbosa.

44 CANECA, Frei Joaquim do Amor Divino - Frei Joaquim do Amor Divino Caneca. Organização e Introdução Evaldo Cabral de Mello. São Paulo: Editora 34, 2001, p. 486 e 561. Frei Caneca foi um dos líderes da revolta 'Confederação do Equador' (1824), com críticas apresentadas à Constituição Imperial: A constituição não garantia a independência do Brasil, pois não definia com clareza o território nacional, a constituição também era contrária à liberdade das províncias pelo excesso de centralismo e não era liberal principalmente por admitir o poder moderador com capacidade de dissolver a Câmara. O argumento mais forte era a imposição do texto constitucional pelo Conselho de Estado e não a promulgação pela Assembleia Constituinte e Legislativa.

45 Em manifesto na reunião popular no Recife para deliberar-se sobre o juramento do Projeto de Constituição, Frei Caneca assim expos suas ideias: "O poder moderador de nova invenção maquiavélica é a chave mestra da opressão da nação brasileira e o garrote mais forte da liberdade dos povos. Por ele o imperador pode dissolver a câmara dos deputados, que é a representante do povo, ficando sempre no gozo dos seus direitos o senado, que é a representante dos apaniguados do imperador. Essa monstruosa desigualdade das duas câmaras, além de se opor de frente ao sistema constitucional, que se deve chegar o mais possível à igualdade civil, dá ao imperador, que já tem de sua parte o senado, o poder de mudar a seu bel prazer os deputados, que ele entender, que se opõem a seus interesses pessoais, e fazer escolher outros de sua facção, ficando o povo indefeso nos atentados do imperador contra seus direitos, e realmente escravos, debaixo porém das formas da lei, que é o cúmulo da desgraça, como tudo agora está sucedendo na França, cujo rei em Dezembro passado dissolveu a câmara dos 
Os idealistas da Confederação do Equador não eram separatistas desde o início, pois apoiaram a Assembleia Constituinte e concordavam com a opção pela monarquia, porém, não concordavam com a centralização do poder estabelecida. As lideranças exaltavam ainda o sistema norte-americano em detrimento dos sistemas europeus que conheciam, os quais, segundo eles, mantinham a centralização política e desprezavam a democracia ${ }^{46}$.

O movimento tornou-se separatista em razão da outorga da Constituição e tentou então estabelecer uma união formada pelas províncias do norte do Brasil, intituladas de Confederação do Equador, em projeto desenvolvido pelo então presidente deposto de Pernambuco Manuel de Carvalho Paes de Andrade ${ }^{47}$. As províncias de Pernambuco, Ceará, Paraíba e Rio Grande do Norte consideravam ilegítima a constituição por ter sido outorgada desprezando o esboço constitucional de 1823 e pela criação do Poder Moderador.

A presença do Poder Moderador era considerada o principal instrumento para a manutenção do poder centralizado nas mãos do Imperador e tolher os direitos do povo. As tendências centralizadoras denotadas no texto constitucional ficaram ainda mais evidenciadas com a reação violenta e autoritária do Império à revolta pernambucana, que foi sufocada militarmente.

O fim da Confederação do Equador não silencia a oposição liberal que desenvolve então novos interesses e assume duas correntes políticas: a primeira contra a monarquia e a sua tendência absolutista; e a segunda contra a centralização nacional buscando o federalismo.

deputados, e mandando-se eleger outros, foram ordens do ministério para os departamentos a fim de que os prefeitos fizessem eleger tais e tais pessoas para deputados, declarando-se lhes logo, que quando o governo empregava a qualquer, era na esperança de que este marchará por onde lhe mostrassem a estrada." CANECA, Frei Joaquim do Amor Divino - «Manifesto». In: BONAVIDES, Paulo; AMARAL, Roberto (orgs.) - Textos Políticos da História do Brasil. Brasília: Senado federal, Conselho editorial, 2002, p. 779.

46 Do manifesto de Proclamação da Confederação do Equador, pelo seu Presidente Manuel de Carvalho Paes de Andrade, em 02 de julho de 1824, extraímos: "Brasileiros! Salta aos olhos a negra perfídia, são patentes os reiterados perjuros do imperador, e está conhecida nossa ilusão ou engano em adotarmos um sistema de governo defeituoso em sua origem, e mais defeituoso em suas partes componentes. As constituições, as leis e todas as instituições humanas são feitas para os povos e não os povos para elas. Eia, pois, brasileiros, tratemos de constituir-nos de um modo análogo às luzes do século em que vivemos; o sistema americano deve ser idêntico; desprezemos instituições oligárquicas, só cabidas na encanecida Europa". ANDRADE, Manuel de Carvalho Paes de - «Manifesto de Proclamação da Confederação do Equador». In: BONAVIDES, Paulo; AMARAL, Roberto (orgs.) - Textos Políticos da História do Brasil. Brasília: Senado federal, Conselho editorial, 2002, p. 786.

47 "Os rebeldes de 1824 não eram desde sempre separatistas. Apoiaram a Constituinte e aceitavam a unidade da América sob o governo do Rio de Janeiro. Não eram sequer irredutivelmente republicanos. Concordavam coma opção monárquica, desde que adotada a federação. Derrotados com o fechamento da Assembleia e a outorga da Carta optaram pela separação e a república”. Cf. DOLHNIKOFF, Miriam - História do Brasil Império. São Paulo: Editora Contexto, 2019, p. 42. 
A maior autonomia das províncias era um interesse comum aos dois grupos, sendo que na segunda vertente a luta pela descentralização política não era contrária à monarquia e defendia uma monarquia federativa ${ }^{48}$.

Após a promulgação da Constituição de 1824 inicia-se seu processo de sua implementação e observa-se a realização de uma série de leis ordinárias e complementares que dão dinâmica à ordem constitucional ${ }^{49}$.

\section{O Ato Adicional e a 'Monarquia Federalista'}

A estrutura político-social do império, modifica-se consideravelmente, porém, desde o período regencial, em 1831, evidenciando novas influências de constitucionalismo e moldando a interpretação da constituição ${ }^{50}$.

Após a abdicação de Dom Pedro I e com o objetivo de diminuir tensões locais, entre os conservadores e os liberais, foi proposta a Lei de Autorização da Revisão da Constituição, em $1832^{51}$, que culminou na alteração da Constituição de 1834, ampliando a dimensão das reformas liberais.

Cabe evidenciar que "a Constituição do império não estabelecia restrições ao poder constituinte derivado. Todos os dispositivos, portanto, eram reformáveis, inclusive o que consagrava a monarquia como forma de governo" e que o Imperador não podia negar a sanção, se aprovada por duas legislaturas seguintes ${ }^{52}$.

48 Sobre a concepção de federalismo no século XIX ver PADOIN, Maria Medianeira - «República, federalismo e fronteira». In: História Unisinos 14(1), Janeiro/Abril 2010, p. 50: "O federalismo - ou a Federação - era concebido, especialmente antes da Carta Constitucional dos Estados Unidos, como um conceito independente do regime político, ou seja, da organização monárquica ou republicana, pois estava vinculado especialmente aos laços ou alianças que congregavam povos e estados, tanto no sentido interno de organização estatal como no aspecto externo. Da mesma forma, o conceito de República como forma de governo ainda não era o único apresentado nos discursos. Sua fundamentação enquanto sociedade/comunidade/estado organizado pela vontade da maioria do seu "povo", em que todos obedecem às mesmas leis (inclusive aquele que a mesma escolhe para governá-la) - de forma que uma monarquia pode ser formada por várias repúblicas -, estava presente inclusive nos discursos de alguns farroupilhas".

49 A legislação 'constitucional' que se desenvolve durante o primeiro reinado e o período regencial prevê a responsabilização dos ministros e conselheiros de Estado (lei de 15/10/1827), a criação e definição de atribuições do Supremo Tribunal de Justiça (lei de 18/09/1828), a criação das câmaras municipais (lei de 01/10/1828), a criação do segundo Conselho de Estado (lei n. 234 de 23/11/1841), cabe aqui evidenciar ainda o decreto n. 523 de 1947 que cria o presidente do Conselho de Ministros.

50 "a verdade político-constitucional é, a maior parte das vezes, uma história externa aos documentos constitucionais [...] um conceito operativo de constituição, no plano historiográfico, deve aproximar-se da forma estrutural político-social de uma época, o que aponta para uma noção de constituição mais ampla do que a de simples documento escrito". Cf. CANOTILHO, José Joaquim Gomes - Direito constitucional. 6. a ed., p. 247.

51 A lei preparatória de reforma da constituição do império, de 12 de outubro de 1832, aprovada na Câmara e no Senado, determinava os artigos da Constituição que seriam objeto de reforma.

52 NOGUEIRA, Octaviano - 1824. 3. ${ }^{\text {a }}$ ed., p. 51. 
O projeto debatido entre as casas legislativas tinha como principais pontos a descentralização do governo, a extinção do Poder Moderador e do Conselho de Estado. A intenção federalista já era clara ${ }^{53}$.

Nicolau Vergueiro, Senador que integrou a Regência Trina provisória, um dos líderes na defesa do projeto de revisão constitucional afirmava:

"O único meio de conservarmos unidas todas as nossas províncias consiste em habilitá-las para poderem curar de suas necessidades e promover a sua prosperidade por meio da influência dos seus próprios governos" 54.

O clamor democrático do projeto de revisão constitucional a ser proposto e discutido entre a Câmara dos Deputados, de maior influência liberal, e o Senado, conservador por excelência, restava claro pois os dois partidos influentes concordavam em adotar as bases necessárias para um governo descentralizado e sua aprovação tinha a intenção de diminuir as tensões políticas que existiam no país, após a abdicação de D. Pedro I em 1831.

Em discurso proferido quando da apresentação do Ato Adicional à Regência pela Câmara dos Deputados, Antonio Paulino Limpo de Abreu, a quem viria a ser concedido o título de Visconde de Abaeté, confirma a intenção dos então deputados com as alterações propostas:

"Senhor, esta obra verdadeiramente da nação, organizada pelos representantes a quem ela delegou esta missão importante, oferece a estrutura de um governo que parece ter sido até agora na Europa o sonho de alguns políticos, mas que vai ser uma realidade na América, uma monarquia sustentada por instituições populares" 55 .

Houve muita moderação e restrição de propostas revisionistas. O desentendimento das casas levou à aprovação final em 9 de agosto de 1834, do Ato de revisão somente pela

53 Nesse sentido, observa-se que a Lei orçamentária de 1832 já previa a divisão entre receitas gerais e provinciais, no final do período regencial observa-se a Lei orçamentária n. 108, de 20 de maio de 1840, que trouxe a classificação dos tributos em receitas gerais, provinciais e municipais. Sobre o movimento federalista na segunda metade do século XIX, no Brasil.Cf. FRAGA, Andrey J. Tafner; DAL RI, Luciene - «A construção do federalismo brasileiro e a constituição de 1891». In: OLIVIERO, Maurizio; LOCCHI, Maria Chiara (org.) - Democracia e constitucionalismo: novos desafios na era da globalização, p. 09-32; BALTHAZAR, Ubaldo Cesar - História do tributo no Brasil. Florianópolis: Fundação Boiteux, 2005, p. 85.

54 DOLHNIKOFF, Miriam - História do Brasil ..., p. 51.

55 ABREU, Antonio Paulino Limpo de - «Apresentação do Ato Adicional à Regência pela Câmara dos Deputados». In: BONAVIDES, Paulo; AMARAL, Roberto (orgs.) - Textos Políticos da História do Brasil. Brasília: Senado federal, Conselho editorial, 2002. p. 931. 
Câmara dos Deputados, gerando debate sobre a sua constitucionalidade, visto que a norma também deveria ter sido aprovada pelo Senado. Tal dúvida foi sanada logo em seguida, em 23 de agosto de 1834 quando o Senado reconheceu a constitucionalidade do Ato Adicional, não se opondo juridicamente a sua aplicação.

As propostas mais extremistas não foram acatadas, sendo mantido o Poder Moderador, a vitaliciedade do mandado dos senadores, assim como a exclusão do uso da expressão "monarquia federativa" ${ }^{5}$.

Entre liberais e conservadores um sentimento permanecia: o Ato Adicional não atendeu ao que almejavam os liberais ao tempo que ultrapassou os limites que os conservadores entendiam ser aceitável para aquele momento ${ }^{57}$. Para os liberais a necessidade de superar o colonialismo ainda esbarrava na estrutura patrimonialista do poder ${ }^{58}$.

O Ato Adicional de 1834 rompeu com a tradição portuguesa de centralização do poder político, criou as assembleias legislativas provinciais, com considerável autonomia para legislarem, e inseriu a participação constitucional do presidente da província na atividade legislativa, bem como unificou a Regência ${ }^{59}$.

56 "Entre o fascínio norte-americano, que já cega muitos teóricos e parlamentares, e a pasmaceira luso monárquica, prevaleceu a permanência do Poder Moderador, do Senado vitalício e a descentralização, esta a verdadeira conquista dos moderados, descentralização que tocaria na estrutura política do edifício monárquico. Todas as reformas teriam uma inspiração maior, que seria o seu limite: a união das províncias, desafogadas de opressivos freios, para melhor garantir a integridade territorial". Cf. FAORO, Raymundo - Os Donos do Poder, p. 354.

57 Nas palavras de Nogueira: "O Ato Adicional, no entanto, como momento de transação entre os dois extremos, um que desejava tudo modificar e o outro que nada admitia mudar, terminou apenas abrandando o rigorismo centralista e instituindo Assembleias Legislativas Provinciais, em lugar dos Conselhos Gerais de Província, que na verdade eram simples órgãos consultivos, sem poderes. As demais aspirações liberais terminaram, na verdade, umas adiadas e nunca realizadas; outras colocadas em ação pela força dos costumes, mas sem se mexer na Constituição, e outras momentaneamente apenas realizadas. Enquanto os liberais exaltados achavam que nada se tinha conseguido, os conservadores radicais acreditavam que se tinha ido longe demais". Cf. NOGUEIRA, Octaciano - «Voluntarismo jurídico e o desafio institucional». In: Revista do Tribunal Regional Federal da 1. ${ }^{a}$ Região. Brasília. ISSN 0103-703-X. Vol. 9, N. . ${ }^{\circ} 3,1997$, p. 51.

58 WOLKMER, Antonio Carlos - História do Direito no Brasil. 5. ${ }^{a}$ ed. , p. 79.

59 Lei n. 16 - Ato adicional à Constituição do Império (12 agosto 1834) art. 10 e 11. Segundo Vieira (VIEIRA, José Ribas - O autoritarismo e a ordem constitucional no Brasil. São Paulo: Renovar, 1988, p. 54) "o colapso da estrutura político-jurídica do Brasil-monárquico não se deve a essas meras crises formais, e sim ao surgimento de novas forças sociais. Elas representam o deslocamento do processo social brasileiro, tanto a nível geográfico, do Vale Paraíba para São Paulo, quanto a mudança dos interesses representados no nível político-social". Faoro, que não contempla com muito entusiasmo o Ato Adicional, diz que ele foi "[...]arrancado não às convicções, mas ao medo dos moderados, procura organizar um feixe de poderes, concentrados nas províncias, de cuja aliança se firmaria o Império. O esquema visa a desmontar, pela descentralização, quase federativa, mas adversa à federação, o centralismo bragantino, ao tempo que foge da fragmentação municipal. Obra de convicção liberal aproximar o governo do povo - e obra de contemporização - fugir do extremado federalismo, casado com ideias

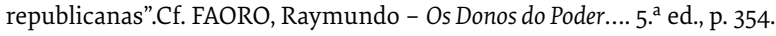




\section{O redator do Ato Adicional à Constituição do Império, Bernardo Pereira de Vasconcelos} era tido como liberal moderado, mas assumiu a posição de líder dos conservadores em 1835 . A redação da única emenda constitucional deixa em dúvida sua real posição política ${ }^{60}$.

Por mais que a criação das assembleias legislativas provinciais pudesse representar um grande salto para a descentralização, pois permitiam legislar sobre diversos e importantes assuntos, como por exemplo a divisão judiciária, civil e eclesiástica das províncias, a instrução pública, a desapropriação por utilidade municipal ou provincial; criação e nomeação para os empregos municipais e provinciais, entre outros ${ }^{61}$, sua funcionalidade não aconteceu, ante as incertezas das atribuições de cada membro ${ }^{62}$.

A ideia da descentralização das províncias era um clamor dos liberais desde a independência, pois a Constituição imposta por D. Pedro I as deixou presas à administração do Imperador $^{63}$. A descentralização trazida com a alteração constitucional era tida por alguns,

60 Bernardo Pereira de Vasconcelos foi deputado geral (1834-1837), apresentou os projetos do Código Criminal do Império do Brasil (1830) e do Ato Adicional (1834), que alterou a Constituição de 1824 e ampliou a dimensão das reformas liberais até então empreendidas. Após 1834 distanciou-se do grupo liberal moderado que integrava, assumindo a liderança conservadora da oposição ao governo do regente Diogo Feijó (1835-37). Voltou ao governo com a renúncia de Feijó e a subida ao poder do conservador Pedro de Araújo Lima, tendo sido indicado secretário de Estado dos Negócios da Justiça (1837-1839) e do Império (1837-1839). Foi nomeado senador (1838-1850) e integrou o Conselho de Estado (1842-1850). Foi reconduzido à pasta do Império em 1840, onde permaneceu por algumas horas, na tentativa de impedir a maioridade de d. Pedro. Com o Golpe da maioridade afastou-se do governo, mas manteve sua atuação política no Senado e no Conselho de Estado. Cf. CARVALHO, José Murilo de -Bernardo Pereira de Vasconcelos. São Paulo: Editora 34, 1999.

61 Lei do Ato Adicional à Constituição do Império (1834), artigos 10, 11 e 12.

62 "Os conselhos-gerais das províncias se elevam a assembleias legislativas provinciais, mantida a nomeação dos presidentes. As províncias, embora desprovidas de autogoverno, ganham o poder legislativo emancipado, com largas interferências e geral tutela sobre os municípios. Entre os três focos verticais do poder - o município, a província e o Império - restaram, entretanto, zonas indefinidas, pelas quais se iriam infiltrar reinvindicações revolucionárias e a pesada mó centralizadora. Sobretudo, as áreas dos governos geral e provincial não lograram, na prática do sistema, fixar um mecanismo de harmonia e entendimento. O quadro constitucional não se mostrou apto a estabelecer a partilha das forças em contraste, de articulação mal definida, num momento em que falta uma estrutura homogênea na sociedade e na economia. " In FAORO, Raymundo - Os Donos do Poder.... $5 .^{\mathrm{a}}$ ed, p. 355.

63 Foi o Ato Adicional, segundo Tavares Bastos “[...]redigido sobre a constituição preparada em 1832. Com quanta inexatidão, pois, afirmar-se-ia que ele é obra da precipitação e do acaso, concessão às paixões do dia, não fruto de ideias amadurecidas! Embora a obscureçam algumas ambiguidades e vícios, aliás de fácil reparação, abençoemos a gloriosa reforma que consumou a independência do Brasil. Não foi o ato adicional, não, um pensamento desconexo e isolado na história do nosso desenvolvimento político. Foi elaborado, anunciado, por assim dizer, pela legislação que o precedera. Inspirou-o a democracia. Ele aboliu o Conselho de Estado, ninho dos retrógrados auxiliares de D. Pedro; decretou uma regência nomeada pelo povo, e permitiu que nossa pátria ensaiasse o governo eletivo durante um grande número de anos; fez mais, criou o poder legislativo provincial. Não é lícito menosprezar obra semelhante“. Cf. TAVARES BASTOS, A. C. - A Província. São Paulo: Companhia Editora Nacional, 1975.p. 63. 
como Visconde de Uruguai ${ }^{64}$, como excessiva pois "entregava às facções que se levantassem nas províncias o Poder Executivo Central de mãos e pés atados”65.

O Ato Adicional foi, portanto, um importante marco para as mudanças nas atribuições político-administrativas tanto das províncias quanto do governo central, porém, o crescimento da instabilidade política gerado pelas revoltas em diferentes províncias - Cabanagem no Pará (1835), Farroupilha no Rio Grande do Sul (1835), a Balaiada no Maranhão (1838) e a Sabinada na Bahia (1837), demonstrou de que a descentralização poderia ser uma ameaça ao regime da Monarquia. O Ato Adicional para muitos trouxe uma "anarquia legislativa", ao passo que pairavam muitas dúvidas acerca das atribuições da assembleia geral e sua possível intervenção nas atribuições das assembleias provinciais ${ }^{66}$.

A vitória liberal então durou pouco tempo e recebeu o contragolpe conservador, por meio da Lei de Interpretação do Ato Adicional de 1834, promulgada em 1840, que estabelecia a restrição dos poderes das câmaras provinciais, em proveito da autoridade central, bem como reduzia os poderes do presidente da província ${ }^{67}$.

64 Visconde de Uruguai e Tavares Bastos travaram grandes debates acerca da centralização e descentralização no Império. O debate entre ambos vem exposto na obra de Ferreira (1999, p. 78) "A diferença entre os olhares de um e outro pode ser localizada no fato de que Uruguai, ao contrário de Tavares Bastos, toma o nosso "caráter nacional" - a falta de tradição de autogoverno, a carência de educação cívica do povo - como o elemento explicativo central de toda a sua análise e argumentação. O erro histórico dos liberais, pensava ele, era considerarem que o despotismo provinha sempre de cima, do abuso da autoridade, e nunca do povo, independentemente de sua educação e seus hábitos. No caso brasileiro, a reforma descentralizadora procurara adaptar instituições próprias dos Estados Unidos em um país que não tinha as pré-condições básicas para suportá-las. Assim é que o chamado Código de Processo, de 1832, entregara importantes atribuições aos juízes de paz, filhos da eleição popular e, portanto, "criaturas da cabala de uma das parcialidades do lugar". Independentes do Poder Administrativo por serem eletivos, eram eles autores dos maiores arbítrios e atentados aos direitos individuais. Do mesmo modo, o Ato Adicional de 1834, e principalmente a "inteligência" que lhe foi dada - atribuindo às Assembleias Provinciais o poder de legislar e nomear para empregos relativos a objetos do Poder Central criou uma descentralização excessiva".

65 URUGUAI, Visconde de - Ensaio sobre o Direito Administrativo. Rio de Janeiro: Departamento de Imprensa Nacional, 1960, p. 380 .

66 Tavares Bastos descreve alguns exemplos acerca das dúvidas em relação à competência legislativa daquele período: "A Câmara dos Deputados em 1836 adia certa proposta do governo sobre habeas- corpus até que se adotasse uma medida sobre a lei de 14 de junho de 1835 da assembleia provincial de Pernambuco. Adia em 1837 um projeto sobre a formação da culpa até que se decidisse a questão sobre empregados gerais e provinciais. Adia, no mesmo ano, outro que elevava a renda para ser jurado, por duvidar-se da competência da assembleia geral para legislar sobre este cargo. O próprio Senado, em 1836, adiara projeto de suas comissões relativo a juízes de paz, municipais e de direito, considerando muitos dos oradores a matéria primitiva das assembleias provinciais". Cf. TAVARES BASTOS, A. C. - A Província, p. 64.

67 - "Quanto a nós, não nos limitaremos a pedir a execução da lei e o abandono de práticas perniciosas; vamos também propor o complemento do sistema esboçado no ato adicional. Este sistema supõe nas províncias um poder legislativo e uma administração próprios: que falta para que funcionem com regularidade? Até onde devemos chegar no empenho de reabilitá-los? Quais as circunscrições da descentralização que os liberais promovem? [...] É tempo! De sobra temos visto uma nação jovem oferecer aos olhos do mundo um espetáculo da decrepitude impotente. Na América, onde tudo devera de ser novo, pretendem que o despotismo se perpetue perpetuando a centralização. O que somos nós hoje? Somos os vassalos do governo - da centralização". Cf. TAVARES BASTOS, A. C. - A Província, p. 78. 
A citada lei que restringia os efeitos da única emenda constitucional imperial, trouxe o restabelecimento do Conselho de Estado, muito embora sem a obrigatoriedade de consulta por parte do Imperador. Os liberais por outro lado sentiram o retrocesso, pois pela legislação que ora se impusera "não se interpretava, amputava-se o ato adicional; e tudo sem os trâmites de uma reforma constitucional: obra por esses dois motivos odiosa"68.

Tido com o "o ato mais enérgico da reação conservadora", a limitação da autoridade das assembleias provinciais entregou novamente a administração da polícia e da justiça para o governo central, com o fundamento da necessidade de manter a integridade da monarquia ${ }^{69}$.

A Lei de Interpretação de 1840, ao lado da Reforma do Código de Processo e do restabelecimento do Conselho de Estado entregou rumos à estrutura política do Segundo Reinado, pois adequou a autonomia provincial à centralização pretendida, trazendo para o governo central a administração da polícia e da Justiça, bem como todos os empregos voltados ao exercício das atribuições do poder central ${ }^{70}$.

Sua promulgação foi fruto de um trabalho dos conservadores na defesa da centralização e, ainda que não revisse a autonomia concedida às províncias pelo Ato Adicional, mantendo o pacto federalista, promoveu os recuos necessários à manutenção do poder da monarquia.

Os debates acerca do binômio centralização/descentralização no império, porém, não acabaram com o Ato Adicional. Os liberais continuaram a buscar a democratização das instituições por meio da descentralização e a restituição da autonomia para as províncias.

Árduo defensor da descentralização, Tavares Bastos ${ }^{71}$ por um lado entende a Lei de Interpretação como um grande retrocesso para as assembleias provinciais, por outro reco-

68 TAVARES BASTOS, A. C. - Cartas do Solitário. São Paulo: Companhia Editora Nacional, 1975, p. 61.

69 FAORO, Raymundo - Os Donos do Poder.... $5^{\text {a }}$ ed., p. 380.

70 "A lei de interpretação (12 de agosto de 1840), elaborada na esteira da apostasia regressista e conservadora de Bernardo Pereira de Vasconcellos, sob o inocente pretexto de elucidar o Ato Adicional, infunde ao estatuto de 1834 alma oposta ao seu contexto. As assembleias provinciais, centro do poder local, cedem, em favor do poder legislativo geral. A polícia e os empregos voltam à corte, duas molas que, desarticuladas do provincialismo, levarão, mais tarde, a justiça e a Guarda Nacional aos pés do ministro da Justiça. A liberdade vigiada, a descentralização consentida, a tutela do alto e de cima ensaiam as primeiras estocadas, prenunciando o quadro fechado da organização política. [...] Duas colunas hão de emergir do aviltamento provincial, para sustentar o edifício imperial: o Conselho de Estado, renascido com a Lei de 23 de novembro de 1841, e a reforma do Código de Processo, renascido com a Lei de 3 de dezembro do mesmo ano. " In FAORO, Raymundo - Os Donos do Poder.... 5. ${ }^{\text {e ed., p. } 379 .}$

71 Para Tavares Bastos, deputado provincial que profundamente estudou os maiores sistemas políticos à sua época, como Estados Unidos, Grã-Bretanha, Canadá e Austrália, entre outros países, a descentralização administrativa era imperativa, e afirmava: "Apreciai as vantagens incomparáveis da administração independente, das liberdades civis e políticas: com menos da metade da nossa população, o Canadá, essa terra hiperbórea da neve, dos lagos e rios gelados, tinha há quatro anos, um movimento comercial igual ao nosso. As sete colônias da Austrália, a quem aliás se dão somente $\mathbf{2 . 0 0 0 . 0 0 0 ~ d e ~ h a b i t a n t e s , ~ m a i s ~ f a v o r e c i d a s ~ p e l a ~ n a t u r e z a , ~ m a s ~ t a m b e ́ m ~ m u i t o ~ m a i s ~}$ distantes, já faziam em 1866 um comércio duplo ao Brasil, e seus governos já dispunham de rendas superiores às nossas. Pungente paralelo!". Cf. TAVARES BASTOS, A. C. - A Província, p. 56. 
nhece que havia a necessidade de melhor interpretar o que prescrevia aquela norma, sua crítica, porém, continua por entender que a necessária interpretação foi realizada ao avesso da natureza da lei em que foi criada ${ }^{72}$.

Se por um lado a articulação da Regência em meio à tensão liberal-conservadora permitiu o diálogo, ou administração das diferenças entre as linhas políticas, fortalecendo politicamente o país, legitimando o poder e superando a herança absolutista portuguesa. Tal fato não impediu, porém, a proclamação da maioridade de Dom Pedro II, diante do perigo de desmembramento ${ }^{73}$. A manobra liberal, que buscou o fim das regências, viu-se, porém, às voltas com a política moderada e tendencialmente conservadora do Imperador Dom Pedro II ${ }^{74}$.

\section{Considerações finais}

O constitucionalismo brasileiro, que nasce e se desenvolve de forma permeada com o constitucionalismo europeu e particularmente português tenta erguer o princípio do governo limitado, dentro de um sistema impregnado de centralização do poder, em acertos e desacertos com os interesses liberais.

O liberalismo na ordem sócio-política brasileira agiu para a independência nacional, mas não impôs inicialmente a república, como nos demais países latino-americanos, lutando pela autonomia, segurança e expansão das relações econômicas e financeiras, bem como pela inserção de direitos e garantias individuais que limitassem o poder do Estado. Observa-se, portanto, desde os primeiros atos constitucionais brasileiros a tendência a ordenar, fundar e limitar o poder político e reconhecer e garantir os direitos e liberdades do indivíduo.

A comunhão de experiência constitucional entre Brasil e Portugal torna-se ainda mais evidente quando da outorga, em Portugal, em 1826, da Carta Constitucional para o Reino

72 "A censura que se faz à lei de 1834, cabe melhor, em verdade, à de 1840. Entretanto, devemos confessá-lo, a experiência havia manifestar a necessidade de interpretar os citados $\S \S$ do ato adicional; havia ela patentear que se devia tirar às assembleias dominadas pela paixão centralizadora pretextos para embaraçarem a autonomia do município". Cf. TAVARES BASTOS, A. C. - A Província, p. 103.

73 SCHWARCZ, Lilia Moritz - As barbas do imperador: Dom Pedro II, um monarca nos trópicos. São Paulo: Companhia das Letras, 1998, p. 74.

74 A influência liberal não ocorreu somente a nível político-constitucional e buscou a regulação da propriedade em âmbito civil. Nesse sentido, ocorreram após o período regencial alguns movimentos infraconstitucionais importantes, como a conversão das sesmarias em propriedade absoluta e individual moderna, com a lei de 1850 e de 1864 colocando em evidencia a influência do liberalismo muito além da constituição (VARELA, 2005, p. 125); e a acomodação de parte dos liberais aos interesses conservadores quando se tratava da "abolição lenta e regular da escravidão" (Lei Feijó de 1831, Lei Eusébio de Queiroz de 1850, Lei Nabuco de Araújo de 1854, Lei do Ventre Livre de 1871, Lei dos Sexagenários de 1885, Lei Áurea de 1888), denotando que o patrimonialismo exacerbado se impôs mesmo diante dos valores de liberdade e de vida humana. Cf. DALLARI, Dalmo de Abreu - A Constituição na vida dos povos. São Paulo: Editora Saraiva, 2010, p. 99. 
de Portugal, Algarves e seus domínios, com texto muito similar à Constituição Política do Império do Brasil, de 1824 .

O liberalismo que fomentou a independência e foi pouco aceito durante o primeiro reinado, influenciou fortemente a elaboração e a dinâmica constitucional sob os demais períodos do Império. A prática constitucional após a abdicação de Dom Pedro I foi além de instrumentos absolutistas, desenvolvendo dinâmica específica. Nesse sentido, observou-se durante o período regencial não apenas descentralização político-administrativa, por meio do Ato Adicional de 1834, mas também práticas constitucionais que aproximaram o Brasil de uma 'experiência republicana'. As aspirações pelo modelo estatal descentralizado e a forma federalista não era unânime nem mesmo entre os liberais, promovendo amplo debate político e doutrinário no Brasil durante todo o segundo reinado.O florescer liberal foi de certa forma contido pelo movimento conservador por meio da Lei de Interpretação, promulgada em 1840, que restringia os poderes das câmaras provinciais e do presidente da província, bem como a declaração da maioridade do Imperador não implicou em grande abertura aos ideais do liberalismo, considerando a postura política moderada e tendencialmente conservadora do Imperador Dom Pedro II.

A prática imperial, porém, desenvolveu sensibilidade não apenas aos interesses dos conservadores e assumiu postura constitucional de forte inspiração inglesa, consubstanciando-se em árbitro na organização política brasileira.

\section{REFERÊNCIAS BIBLIOGRÁFICAS}

ABREU,Antonio Paulino Limpo de - «Apresentação do Ato Adicional à Regência pela Câmara dos Deputados».

In: BONAVIDES, Paulo; AMARAL, Roberto (orgs.) - Textos Políticos da História do Brasil. Brasília: Senado

Federal, Conselho editorial, 2002.

ANDRADE, Manuel de Carvalho Paes de - «Manifesto de Proclamação da Confederação do Equador».

In: BONAVIDES, Paulo; AMARAL, Roberto (orgs.) - Textos Políticos da História do Brasil. Brasília: Senado

Federal, Conselho editorial, 2002.

ARISTOTELES - Política. $4 .^{\text {a }}$ ed. Roma-Bari: Laterza, 1997.

BALTHAZAR, Ubaldo Cesar - História do tributo no Brasil. Florianópolis: Fundação Boiteux, 2005.

BOBBIO, Norberto - Liberalismo e Democracia. São Paulo: Ed. Brasiliense, 2000.

BONAVIDES, Paulo - História constitucional do Brasil. Rio de Janeiro: Paz e Terra, 1991.

BONAVIDES, Paulo - «A evolução constitucional do Brasil». In: Estudos Avançados. São Paulo. ISSN 0103-4014.

Vol. 14, N. $.^{\circ} 40,2000$.

BONAVIDES, Paulo - Teoria constitucional da democracia participativa. São Paulo: Malheiros, 2001.

BONAVIDES, Paulo - «As nascentes do constitucionalismo luso-brasileiro, uma análise comparativa».

[Consultado em: 30 de Agosto de 2019] Disponível em https://archivos.juridicas.unam.mx/www/bjv/

libros/4/1510/9.pdf.

BRAZ, Florentino Henrique de Souza - Do poder moderador. Recife: Typographia Universal, 1864. 
BRITO, Jorge e EICHLER, Athos - Um texto desconhecido sobre a Constituição de 1823. In Fragmentos de estudos da história da Assembleia Constituinte do Brasil. Brasília: Senado Federal, Conselho Editorial, 2006.

BUENO, José Antônio Pimenta - Marquês de São Vicente. Organização e introdução de Eduardo Kugelmas. São Paulo: Editora 34, 2002.

MELLO, Evaldo Cabral de (Organização e Introdução)- Frei Joaquim do Amor Divino Caneca. -. São Paulo: Editora 34, 2001.

CANECA, Frei Joaquim do Amor Divino - «Manifesto». In: BONAVIDES, Paulo; AMARAL, Roberto (orgs.) Textos Políticos da História do Brasil. Brasília: Senado federal, Conselho editorial, 2002.

CANOTILHO, José Joaquim Gomes - Direito constitucional e Teoria da Constituição. 6. ${ }^{\mathrm{a}}$ ed. Coimbra: Almedina, 1993.

CANOTILHO, Joaquim José Gomes - «As Constituições». In: José Mattoso (org.) - História de Portugal - Vol. V. Lisboa: Círculo de Leitores, 1993.

CARVALHO, José Murilo de - Bernardo Pereira de Vasconcelos. São Paulo: Editora 34, 1999.

CERQUEIRA, Marcello - Cartas Constitucionais: Império, República e Autoritarismo. Rio de Janeiro: Renovar, 1997.

CONSTANT, Benjamin - Escritos de política. São Paulo: Martins Fontes, 2005.

CONSTANT, Benjamin - Principes de politique applicables a tous les gouvernemens représentatifs et particulièrment a la constitution actuelle de la France. Paris: Ches Alexis Eymery, De l'imprimerie de Hocquet, 1815.

CORRÊA, Darcísio - A construção da cidadania. Reflexões histórico-políticas. Ijuí: Unijuí, 2006.

DAL RI Jr., Arno - «Evolução histórica e fundamentos políticos-jurídicos da cidadania». In: DAL RI JR., Arno; OLIVEIRA, Maria Odete de (org.) - Cidadania e Nacionalidade: efeitos e perspectivas: nacionais - regionais - globais. Ijui: Unijuí, 2002.

DAL RI, Luciene - «A construção da cidadania no Brasil: entre Império e Primeira República». In: Espaço Jurídico Journal of Law [EJJL]. Joaçaba. E- ISSN 2179-7943, vol. 11(1), p. 7-36, 2011.

DAL RI, Luciene - «Os direitos políticos no Brasil Imperial: entre constitucionalismo e liberalismo». In: Direitos Fundamentais \& Justiça. Porto Alegre. ISSN 0100-9079, vol. 18, p. 129-148, 2012.

DALLARI, Dalmo de Abreu - A Constituição na vida dos povos. São Paulo: Editora Saraiva, 2010.

DEIRÓ, Pedro Eunápio da Silva - Fragmentos de estudos da história da Assembleia Constituinte do Brasil. Brasília: Senado Federal, Conselho Editorial, 2006.

DOLHNIKOFF, Miriam - História do Brasil Império. São Paulo: Editora Contexto, 2019.

FAORO, Raymundo - Os Donos do Poder. Formação do patronato político brasileiro. $5 .^{\mathrm{a}}$ ed. Rio de Janeiro: Editora Globo, 2018.

FERREIRA, Manuel Rodrigues - A evolução do Sistema Eleitoral Brasileiro. Brasília: Senado Federal, 2001.

FERREIRA, Gabriela Nunes - Centralização e Descentralização no Império. O debate entre Tavares Bastos e visconde de Uruguai. São Paulo: Editora 34, 1999.

FIORAVANTI, Maurizio - Costituzione. Bologna: Il Mulino, 1999.

FRAGA, Andrey J. Tafner; DAL RI, Luciene - «A construção do federalismo brasileiro e a constituição de 1891». In: SANTOS, Rafael Padilha; DAL RI, Luciene; SOARES, Josemar Sidinei (org.) - Democracia e constitucionalismo: novos desafios na era da globalização. Perugia: UNIVALI, UNIPG, 2017.

HARRINGTON, James - «The Commonwealth of Oceana». [Consultado em: 23 de Março de 2010] Disponivel em: http:// www.constitution.org/jh/oceana.htm.

HERKENHOFF, João Baptista - Como funciona a cidadania. 2 ed. Manaus: Editora Valer, 2001.

HESPANHA, Manuel - «Sob o signo de Napoleão. A Súplica constitucional de 1808». In: Almanack braziliense. São Paulo. ISSN 1808-8139. V.8, 2008.

HESPANHA, António Manuel - Pequenas repúblicas, grandes Estados. Problemas de organização política entre antigo regime e liberalismo. Brasil. Formação do Estado e da Nação. São Paulo-Ijuí: Ed. Unijuí, 2003.

HORTA, José Luiz Borges - Direito Constitucional da Educação. Belo Horizonte: Editora Decálogo, 2007. 
KANT, Immanuel - Über den Gemeinspruch ,Das mag in der Theorie richtig sein, taugt aber nicht fûr die Praxis: Frankfurt-am-Main: Klostermann, 1992.

LOPES, José Reinaldo de Lima - O Direito na História: lições introdutórias. 3. ${ }^{a}$ ed. São Paulo: Atlas, 2008.

LOVE, Joseph L. - «A república brasileira: federalismo e regionalismo (1889-1937)». In: MOTA, Carlos Guilherme (org.) Viagem incompleta. A experiência brasileira. São Paulo: Ed. Senac, 2000.

MELLO, F. I. Marcondes Homem de - Escriptos históricos e literários. $2^{\circ}$ ed. Rio de Janeiro, 1866.

MARSHALL, Thomas Humprey - Cidadania, Classe Social e Status. Rio de Janeiro: Zahar Editores, 1967.

NABUCO, Joaquim - O abolicionismo. São Paulo: Publifolha, 2000.

NOGUEIRA, Octaviano - 1824. 3. Ed. Brasília: Senado Federal, Coordenação de Edições Técnicas, 2018.

NOGUEIRA, Octaciano - «Voluntarismo jurídico e o desafio institucional». In: Revista do Tribunal Regional Federal da 1. ${ }^{a}$ Região. Brasília. Vol. 9, N. ${ }^{\circ}$ 3, 1997, p. 51.

PADOIN, Maria Medianeira - «República, federalismo e fronteira». In: História Unisinos 14(1):49-54, Janeiro/ Abril 2010.

PIMENTA BUENO, José Antônio - Marquês de São Vicente. São Paulo: Editora 34, 2002.

PIRES, Alex Sander Xavier; TRINDADE, Carla Dolezel;AZNAR Filho, Simão - Constitucionalismo Luso-Brasileiro - leitura normativa no âmbito do domínio da lei e da humanização das relações. Rio de Janeiro, 2017.

SCHWARCZ, Lilia Moritz - As barbas do imperador: Dom Pedro II, um monarca nos trópicos. São Paulo: Companhia das Letras, 1998.

SIEYES, Emmanuel-Joseph - Préliminaire de la constitution françoise. Reconnoissance et exposition raisonnée des droits de l'homme et du citoyen. Versailles, 1789.

SILVA, José Afonso da - Curso de Direito Constitucional Positivo. São Paulo: Malheiros, 1998.

TAVARES BASTOS, A. C. - A Província. São Paulo: Companhia Editora Nacional, 1975.

TAVARES BASTOS, A. C. - Cartas do Solitário. São Paulo: Companhia Editora Nacional, 1975.

TEIXEIRA DE FREITAS, Augusto - Consolidação das leis civis. 3. ${ }^{a}$ ed. Brasília: Senado federal, Conselho editorial, 2003 (1876).

MASON, George; LEE, Tjomas Ludwell; NICHOLAS, Robert Cartes; MADISON, James - The Virginia Declaration of Rights, 1776.

VARELA, Laura Beck - Das sesmarias à propriedade moderna: um estudo de história do direito brasileiro. Rio de Janeiro, São Paulo, Recife: Renovar, 2005.

VIEIRA, José Ribas - O autoritarismo e a ordem constitucional no Brasil. São Paulo: Renovar, 1988.

URUGUAI, Visconde de - Ensaio sobre o Direito Administrativo. Rio de Janeiro: Departamento de Imprensa nacional, 1960.

CARVALHO, José Murilo de (Org. e introd.) - Visconde de Uruguai. São Paulo: Editora 34, 2002.

WOLKMER, Antonio Carlos - História do Direito no Brasil. 5. ${ }^{a}$ ed. Rio de Janeiro: ed. Forense, 2009.

Outras Fontes:

ASSEMBLÉE NATIONALE CONSTITUANTE. Declaration des Droits de l'homme et du Citoyen, 1789.

Carta Constitucional para o Reino de Portugal, Algarves e seus domínios, 1826.

ESPANHA. Constituição de Cádiz - Constituição Política da Nação Espanhola, 1812.

PORTUGAL. Constituição Política da Nação Portuguesa, 1822.

BRAZIL. Constituição Política do Império do Brazil, 1824

BRASIL. Constituição da República dos Estado Unidos do Brasil, 1891. 